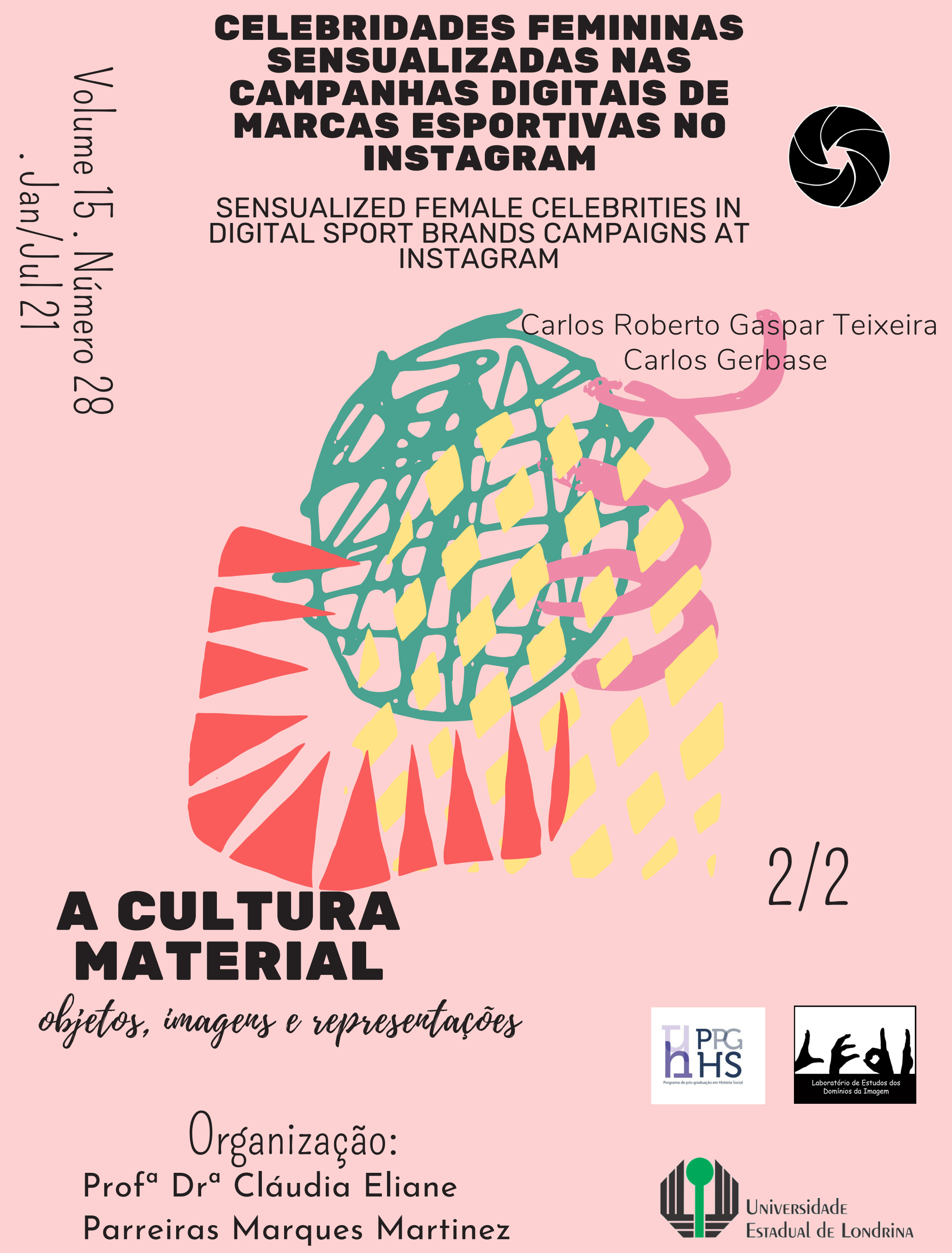




\section{CELEBRIDADES FEMININAS SENSUALIZADAS NAS CAMPANHAS DIGITAIS DE MARCAS ESPORTIVAS NO INSTAGRAM'}

\section{FEMALE CELEBRITIES SENSUALIZED IN THE DIGITAL CAMPAIGNS OF SPORT BRANDS ON INSTAGRAM}

\author{
Carlos Roberto Gaspar TEIXEIRA² \\ Carlos GERBASE ${ }^{3}$
}

Resumo: A partir dos atuais esforços sociais contra a objetificação da figura feminina, esse artigo busca examinar como as marcas esportivas se comportam nesse contexto. Para isso, foram analisados os perfis oficiais das principais marcas esportivas no Instagram, sendo possível identificar a existência de resquícios de uma representação feminina sensualizada. Foram coletadas e categorizadas 1.776 imagens, entre fotos e vídeos, dos perfis globais e nacionais das empresas Nike, Adidas, Reebok e Puma, que possibilitaram observar que as marcas que não lideram o mercado exploram a representação feminina de figuras públicas não ligadas ao esporte. Também se notou que os perfis brasileiros das marcas reforçam o imaginário nacional acerca da sensualidade feminina com postagens que, de algum modo, valorizam a uma representação sensual das mulheres patrocinadas.

Palavras-chave: Sensualidade; Mulheres; Marcas Esportivas; Instagram

\begin{abstract}
From the current social efforts against the "objectification" of the female figure, this article seeks to examine how sports brands behave in this context. For that, the official Instagram profiles of the main sports brands were analyzed, being possible to identify the remnants of feminine representation. A total of 1,776 images, including photos and videos, were collected and categorized from national and global Instagram companies' profiles of Nike, Adidas, Reebok and Puma, which made it possible to observe that non-market leaders brands exploit female representation of public figures not related to sport. It has also been noted that Brazilian brand profiles reinforce the national imaginary about female sensuality, with posts that somehow value a sensual representation of sponsored women.
\end{abstract}

Keywords: Sensuality; Women; Sports Brand; Instagram
10 presente trabalho foi realizado com apoio da Coordenação de Aperfeiçoamento de Pessoal de Nivel Superior - Brasil (CAPES) - Código de Financiamento 001.

2 Mestre em Comunicação Social pela Pontifícia Universidade Católica do Rio Grande do Sul, Porto Alegre-RS, doutorando do Programa de Pós-Graduação em Comunicação Social da Pontifícia Universidade Católica do Rio Grande do Sul, Porto Alegre, RS. E-mail: eu@ocarlosteixeira.com.br. Orcid: https://orcid. org/0000-0001-68291682

3 Pós-doutor em Cinema pela Université Sorbonne Nouvelle - Paris 3 . Doutor em Comunicação Social pela Pontifícia Universidade Católica do Rio Grande do Sul, Porto Alegre-RS. Professor titular (2005-2021) no Curso de Produção Audiovisual e no Programa de Pós-Graduação em Comunicação da Pontifícia Universidade Católica do Rio Grande do Sul, Porto Alegre, RS. E-mail: gerbase@ pranafilmes.com.br. Orcid: https://orcid. org/0000-0001-92155840 . 


\section{INTRODUÇÃO}

Questões de gênero e erotização do corpo feminino são temas frequentemente discutidos em pesquisas na área de Comunicação, pois as mídias parecem desempenhar um papel importante na construção de um imaginário da mulher sensualizada. No Brasil, os inúmeros casos de possíveis propagandas sexistas resultaram na aprovação de um projeto de lei na Assembleia Legislativa do Rio de Janeiro (Alerj) que prevê multa de até 1,3 milhão de reais às empresas que veicularem propagandas com algum tipo de conteúdo misógino, sexista ou que estimule a violência contra a mulher (COPLE, 2018). No âmbito esportivo, parece surgir, também, uma preocupação acerca dessas questões. Numa breve análise das últimas três Copas do Mundo, é possível constatar indícios de um movimento contra a representação sensualizada da mulher.

Em 2010, na Copa do Mundo da África, a figura da modelo Larissa Riquelme pôde ser apontada como um dos "símbolos" da representação sensual feminina. Ela ficou mundialmente famosa a partir da divulgação de sua foto em que celebrava um gol da seleção paraguaia com um farto decote e seu celular alojado entre os seios. De acordo com o portal Globoesporte (LARISSA..., 2010), a paraguaia se tornou a "Namorada do Mundial", “despontando para o estrelato com seu famoso 'porta celular". Na Copa do Mundo do Brasil, quatro anos mais tarde, as imagens das belas torcedoras também foram recorrentes, amparadas pela cultura nacional da praia, do biquíni e das beldades. Frequentemente, torcedoras bonitas eram exibidas, durante as transmissões ou em matérias e notícias sobre o evento ${ }^{4}$. Em 2018, na Copa da Rússia, parece ter se atingido um "ponto de virada" para a exibição de mulheres sensuais nesse tipo de acontecimento. A Fifa solicitou que as emissoras evitassem filmar "torcedoras atraentes" durante as partidas (FIFA..., 2018). A Getty Images, uma das maiores agências de fotografia do mundo, recebeu críticas por publicar uma galeria das "Torcedoras mais sexys", o que resultou na remoção das imagens do ar, assim como em um comunicando oficial de pedido de desculpas (MATOS, 2018). É possível também ressaltar que, durante a última edição da competição, foram registrados, oficialmente, 45 casos de assédio sexual (CHADE, 2018). Toda a preocupação acerca dos possíveis assédios se amplificou com o caso dos vídeos de torcedores brasileiros assediando torcedoras russas que circularam nas redes sociais digitais (MAIS..., 2018).

Não é só no futebol que questões ligadas ao gênero feminino, representações inadequadas e preconceito dentro do âmbito esportivo aparecem. O Comitê Olímpico Internacional tem concentrado esforços na igualdade de gêneros, sendo essa uma das principais recomendações no acordo conhecido como Agenda Olímpica 2020, aprovado em 2014, que visa estabelecer uma visão clara do futuro do Movimento Olímpico (IOC, 2014b). Conforme mensagem do presidente da entidade, Thomas Bach, o esporte
4 Ao realizar uma busca no Google pelo termo "Torcedoras Copa do Mundo 2014" é possivel encontrar diversas matérias, imagens e vídeos, abordando temas como: seleção das mais belas, torcedoras mais gatas, etc. Disponível em: https://www.google. $\mathrm{com} / \mathrm{search}$ ?q=torcedoras+copa+mundo $+2014 \&$ client $=$ safari\&rls=en\&iw $=1478 \&$ bih=969\&ei=xFUKXPqwMIj4wA 
tem papel fundamental e deve ser utilizado para promover os direitos e o bem-estar das mulheres e meninas ao redor do mundo (IOC, 2014a).

Não são raros os estudos que apresentam dados e discussões acerca de como as mídias geralmente retratam representações estereotipadas e sensualizadas de mulheres, transmitindo a noção da objetificação feminina (FREDRICKSON; ROBERTS, 1997; WARD; HARRISON, 2005; MORENO, 2012; WARD et al., 2013), também relacionando esta temática ao esporte (GOELLNER, 2008; DANIELS; WARTENA, 2011).

Existem reiterados esforços sociais, culturais e comunicacionais que buscam uma valorização da imagem da mulher, sem enfatizar sua representação por meio de atributos físicos. A objetificação feminina, a partir de artifícios que realçam a sensualidade, é hoje politicamente incorreta. Esse movimento parece ser reforçado ao se observar especificamente a combinação entre os meios de comunicação, o esporte, de modo mais amplo, e as investidas publicitárias ligadas ao marketing. O ano de 2018 se apresentou como marcante nesse sentido, principalmente com as ocorrências já citadas aqui. Nesse sentido, este artigo busca identificar existência da utilização mercadológica da mulher de forma objetificada, além de, se caso aconteça, como isso ocorre dentro da mídia social Instagram, em especial nos perfis de marcas esportivas. Aqui, entende-se a objetificação feminina como os modos de representação da mulher que enfatizam principalmente uma imagem que enfoca exageradamente o sensual ou o erótico. Os dois advérbios da frase anterior não são gratuitos. A representação do corpo feminino nas artes em geral (e na publicidade em particular) não é uma ação "errada". Esta é uma visão moralista e tacanha. A situação que criticamos é a estratégia publicitária de, intencionalmente, reduzir a representação da mulher modelo à sua sensualidade, esquecendo outros aspectos fundamentais do feminino. O erotismo só é opressor e contribui com a objetificação feminina se da mulher é retirada a sua subjetividade e a sua autonomia, submetendo-a a um papel de alvo passivo do olhar masculino. Embora sutil, e sujeito a diferentes pontos de vista em diferentes campos culturais, esse aspecto da discussão é fundamental: nossa análise está centrada no uso publicitário do corpo feminino nas situações descritas, e não na arte fotográfica e audiovisual em geral. Aspecto explorado, entre outros, por Daniels e Wartena (2011), ao investigarem as representações midiáticas de atletas mulheres, destacando como os meios de comunicação tendem a representar esportistas femininas de forma objetificada e sexualizada.

\section{CHOQUE DE BELEZAS}

No capítulo 17 da obra "História da Beleza”, chamado “A beleza da mídia”, Umberto Eco afirma que boa parte do século 20 (pelo menos até os anos 60) assistiu a uma luta entre a beleza da provocação e a beleza do consumo. A primeira é filha das vanguar- 
das modernistas, "do futurismo ao cubismo, do experimentalismo ao surrealismo, de Picasso até os grandes mestres da arte informal e além” (ECO, 2004, p. 415). Uma pintura dessa fase não se esforça para ser "bela", segundo os cânones seguidos por Rafael ou Giotto. Elas são belas por quebrarem esses cânones, por ensinarem a ver corpos e paisagens de outra maneira, mais ligados às pulsões do inconsciente do que às velhas proporcionalidades da Grécia clássica e da Renascença.

Na opinião de Jonah Lehrer, Paul Cézanne tem uma participação fundamental nessa quebra de paradigmas, a partir da sua exposição de 1910, em Paris. Os quadros da mostra foram taxados de doentios, uma coleção de distorções patológicas da natureza. Mas as obras de Cézanne "eram sobre a subjetividade da visão, a ilusão das superfícies. Cézanne inventou o pós-impressionismo porque os impressionistas não eram estranhos o suficiente" (LEHRER, 2010, p. 149). Hoje sabemos que Cézanne estava antecipando descobertas da neurociência, que já provou a participação decisiva do cérebro na formação da imagem e na interpretação de qualquer obra de arte. Cézanne provocou tanto, e de forma tão radical, as regras de beleza de sua época, que seus quadros eram chamados de feios. Hoje, é claro, são disputados em leilões com lances de dezenas de milhões de dólares.

No outro lado da luta, segundo Eco (2004), está a beleza de consumo. Ela não se baseia na estética dos vanguardistas, e sim no que está nas capas das revistas de moda, nas novelas de TV, nos filmes, nos jornais, na mídia. No momento em que o texto de Eco foi escrito, quase 20 anos atrás, costumava-se dizer que a beleza era gerada pelos meios de comunicação de massa. Hoje, com certeza, podemos dizer que ela também surge nos blogs dos "influencers", nos posts do Facebook e do Instagram, nas redes sociais digitais em geral. Estas alimentam-se, em grande parte, da agenda proposta pelos mass-media, num diálogo que a moda e a publicidade, pouco a pouco, aprendem a utilizar para seus próprios fins, como atesta Lipovetsky (1989). Manovich (2016) ressalta o papel das mídias sociais nesse processo da cultura de massa por meio das novas tecnologias. O Instagram, plataforma surgida em 2010, segundo o autor, já pode ser visto como um meio de comunicação, com um papel fundamental na história da mídia moderna. Esse site de rede social se enquadra como uma nova mídia de massa, utilizada por milhares de pessoas, enfatizando a estética visual por meio do compartilhamento de imagens (MANOVICH, 2016).

O suposto choque violento entre as duas belezas tão diferentes transformou-se numa aparente harmonia de contrários. Primeiro a Pop Art, depois as experimentações pós-modernas (que gostam de revisitar ironicamente os cânones clássicos) promoveram uma "orgia de tolerância, de sincretismo, de absoluto e irrefreável politeísmo da Beleza" (ECO, 2004, p. 428). Assim, podem ser belas as modelos quase anoréxicas (como Kate Moss), mas também são belas as garotas de formas avantajadas (como Claudia Schiffer). 
São admiráveis, igualmente, os corpos atléticos, moldados nas academias de ginástica e no esporte, mesmo que eles estejam a serviço da música (como Anitta).

De certo modo, estamos revisitando o culto à força dos músculos, que já foi classificado de fascista (como nas acusações ao filme Olympia, de Leni Riefenstahl) ${ }^{5}$. Entretanto, agora não se trata mais de uma celebração racista, e sim de uma ode à saúde. As modelos negras podem participar sem problema algum. Aliás, elas têm que participar. Assim podem comprar as roupas justas e coloridas que cobrem (mas não muito) as peles de todos os tons que constroem a beleza do consumo que domina o século 21 . Os músculos não têm raça. Quanto à beleza da provocação, também participa da dança, principalmente no design das peças, que volta e meia pretendem ser futuristas, desconstruídas, cyberpunks ou naturais (sem agressões à natureza, sem agrotóxicos, etc.). É nesse contexto que as grandes empresas de vestuário esportivo atuam em suas estratégias de marketing. É preciso ter cuidado com a objetificação feminina, mas tanto as modelos quanto os profissionais da publicidade sabem que a natureza humana apenas deu mais uma volta cultural sobre si mesma, e que o apelo sexual não pode ser desprezado. (LIPOVETSKY, 2000). Pelo contrário: deve (na lógica das vendas) voltar remodelado, com uma nova máscara, que atraia homens e mulheres, na fronteira, por vezes, bem nebulosa do politicamente correto.

\section{CULTURA MATERIAL, CONSUMO E A MULHER SENSUALIZADA}

Ao buscar analisar os modos como as imagens femininas são utilizadas em campanhas digitais de artigos esportivos é possível estabelecer uma relação direta entre a cultura material, o consumismo e a mulher representada de forma sensualizada. Segundo Miller (2007), os estudos de cultura material partem da especificidade de objetos materiais para compreender que a humanidade é inseparável de sua materialidade. Contudo, o autor (MILLER, 2007, p. 49) usa o vestuário e seu design como exemplo da amplificação do entendimento da cultura material contemporânea que focam exclusivamente no objeto, para uma compreensão social mais aprofundada, considerando os “[...] efeitos do vestuário sobre os usuários”. Miller (2007, p. 50) ainda ressalta o papel da mídia nesse processo, onde "[...] estudiosos de cultura material têm buscado ampliar essas mudanças prestando atenção maior no papel da materialidade em formas de mídia específicas e no impacto subseqüente sobre a criação da socialidade”. De acordo com Campbell (2006), a identidade social do indivíduo pode ser encontrada em suas relações com os produtos e não com os produtos em si. A partir dessas reflexões é possível considerar o consumo e a cultura material como representações do comportamento social na modernidade.

Nesse contexto é possível associar as relações feministas com os produtos midiáticos e com a cultura material. Conforme destacam Sabiston e Wilson (2006), o uso de
${ }^{5}$ Olympia foi um filme documentário sobre os Jogos Olímpicos de Verão de Berlim em 1936 produzido e dirigido por Leni Riefenstahl, apontado por muitos como uma obra prima cinematográfica e também amplamente criticado por ser considerado um produto de propaganda nazista patrocinado por Hitler (HOLMES, 1974). 
celebridades para construir a percepção midiática do corpo atlético ideal é algo frequente, onde a relação entre corpo, gênero, saúde, mídia e celebridades femininas determinam uma retórica sexual em torno do corpo, especialmente nos espetáculos musicais e esportivos. Ao analisar gênero, mídia e identidade, Gauntlett (2003, p. 197) cita que a objetificação de celebridades é um processo que ocorre há décadas em veículos midiáticos e na propaganda, sugerindo um espelhamento desse comportamento, originário das revistas masculinas, mas já repetido nas publicações focadas principalmente para mulheres. Gill $(2006,2007)$ ressalta como muitas das representações midiáticas femininas tendem a retratar as mulheres como objetos enfatizando suas curvas.

É possível inferir que existe, não raramente, uma apropriação mercadológica dos corpos femininos. Esse processo reforça as limitações e recorrentes tendências midiáticas na utilização das mulheres ainda como objetos e de modo sensualizado. Diversos são os estudos que apresentam dados e discussões acerca de como as mídias geralmente retratam representações estereotipadas e sensualizadas de mulheres, transmitindo a noção da objetificação feminina (WARD; HARRISON, 2005; MORENO, 2012; WARD et al., 2013).

A teoria da objetificação, de Fredrickson e Roberts (1997), argumenta que as sociedades atuais representam o corpo feminino como um objeto sexual de forma rotineira, algo que acontece, entre outros fatores, por meio das experiências dos indivíduos com as mídias visuais. Daniels e Wartena (2011), em especial, analisam como a mídia utiliza imagens de atletas femininas enfatizando sua aparência física, por muitas vezes, de forma sexualizada. Esse processo avançou recorrentemente, de acordo com Salvini, Souza e Marchi Junior (2012, p. 405), ao se construir uma história ocidental dos esportes, “[...] foram indicadas as mulheres práticas esportivas que reforçassem caracteres estéticos, ‘feminis' e de eugenização”.

Desse modo, entende-se como objetificação a exploração visual do corpo feminino, onde "a propaganda cria uma economia visual em que a mulher se torna um objeto oferecido para o homem (e para os espectadores)" (GILL, 2007, p. 53). Gill (2007) ressalta que a publicidade investiu por muito tempo na transformação da sexualidade feminina em fetiche e commodities, associando-a com a beleza, corpos jovens em busca de prazer. Segundo Bourdieu (1999, p. 82), a "dominação masculina constitui as mulheres como objetos simbólicos [...]", colocando-as em um estado permanente de insegurança e dependência simbólica, fazendo com que elas existam "[...] primeiro pelo, e para, o olhar dos outros, ou seja, enquanto objetos receptivos, atraentes, disponíveis".

As reflexões de Segato (2003), combinando violência e gênero, permitem estabelecer uma aproximação dessa objetificação feminina ao universo digital. A autora ressalta, entre outros pontos, a presença de uma economia do desejo na internet, que permi- 
te, mesmo que de modo velado, a manutenção dessa dominação patriarcal, que acaba por estereotipar a figura feminina objetificada. A sexualidade é um aspecto inerente a esse processo de objetificação da mulher, principalmente analisado sob o ponto de vista midiático e comunicacional. Foucault (2000, p. 236) estabelece uma reflexão sobre a história da sexualidade, destacando-a como "[...] um comutador que nenhum sistema moderno de poder pode dispensar", sendo consequência de uma sociedade voltada para o consumo.

Ao relacionar esses pensamentos com o contexto cultural brasileiro, esse processo parece ganhar ainda mais relevância. Freyre (2002) argumenta a existência de sociedade patriarcal no Brasil, na qual a mulher ainda está presente como ornamento, com exacerbação da sexualidade. Bocayuva (2001), analisando a obra de Freyre, ressalta que o excesso sexual ainda está vigente em nossos dias. Tal fato é ampliado por Malheiros e Padilla (2015), ao discutirem sobre como o corpo feminino das brasileiras é percebido como um elemento fundamental para a compreensão cultural do país, onde a centralidade do corpo relacionado com a beleza são aspectos reforçados como um traço legitimamente brasileiros. De acordo com Goldenberg (2010), os corpos das mulheres brasileiras podem ser entendidos como um capital da cultura nacional, sendo recorrentemente retratados midiaticamente como "atraentes, invejados e imitados".

A propaganda brasileira, como ressalta Beleli (2007, p. 202), historicamente está ancorada em atributos de gênero que transparecem a beleza do corpo da mulher brasileira, onde “os corpos femininos [...] são expostos como um 'patrimônio', um capital cultural que suplanta a inteligência, a competência, atributos tidos como constituidores de masculinidade. A bunda é um alvo preferencial na propaganda, particularmente no Brasil”. Nesse sentido, Lessa (2005) enfatiza a "bundalização" da mídia, que implica na ênfase da publicidade em mostrar um padrão de corpo comumente encontrado na mulher brasileira.

Por outro lado, é importante ressaltar reflexões que observam as transformações dessas representações femininas. Santaella (2008) destaca uma nova mulher, chamada de "híbrida", que se importa com identidade, sucesso, liberdade, maternidade, sexualidade, moralidade, cidadania e trabalho. Nessa mesma linha, Lipovetsy (2000) propõe o conceito da "terceira mulher", que transcende os princípios feministas, sendo ela dona do seu destino, corpo e posição social. Tal processo, segundo o autor, diminuiu as diferenças entre os gêneros, porém mantém as identidades femininas e masculinas vigentes.

Considerando todos os fatores apresentados, o presente artigo busca analisar, amparado nas questões da cultura material, e considerando como objeto os perfis digitais das marcas esportivas brasileiras e suas postagens no Instagram, a presença de um modelo mercadológico que ainda parece explorar a imagem de celebridades femininas ressaltando a sensualidade, de forma a gerar uma representação objetificada das mulheres. 


\section{ATORES ESPORTIVOS E INSTAGRAM}

Ao analisar o contexto esportivo é possível elencar alguns "atores" presentes entre os possíveis "responsáveis institucionais" da representação simbólica feminina nos esportes. Denominados aqui como "atores esportivos", seriam eles: a) os órgãos oficias e comitês - como a Fifa, COI, Federações e comissões mundiais e nacionais; b) os atletas e membros das equipes - todos aqueles envolvidos diretamente na prática esportiva direta; c) os meios de comunicação responsáveis pelas transmissões esportivas; d) as empresas ou marcas, que constituem o amparo financeiro para o desenvolvimento esportivo por meio de patrocínios e apoios. Esses atores podem ser considerados alguns dos principais responsáveis pela construção da imagem feminina no esporte.

A presente análise estabeleceu a rede social digital Instagram como o recorte da pesquisa. Foi selecionada essa plataforma devido ao seu foco principal no visual, priorizando o compartilhamento de imagens (fotos e vídeos) e tendo índices de crescimento do número de usuários relevantes nos últimos anos (COM 50..., 2017; INSTAGRAM..., 2018). O tipo de imagem que é compartilhada pelos atores nessa rede possivelmente dá indícios do comportamento e da contribuição das partes na construção de uma representação feminina. Nesse sentido, essa plataforma, sob a perspectiva da cultura material, pode ser compreendida não só como um "repositório representativo de artefatos", mas também analisada em relação aos contextos: a) social - de quem as criou; b) econômico - de quem a produziu; mercadológico - que a distribuiu e d) cultural - por sua concepção estética.

Todos os atores envolvidos podem ser discutidos a partir desse viés, todavia, para a presente análise, não foram considerados os meios de comunicação, por não serem essenciais dentro da plataforma, que é independente e pode ser considerada um meio em si; e os atletas e membros das equipes, por se enquadrarem em perfis individuais e pessoais, onde eles próprios são os responsáveis por suas imagens. Focando então primeiramente nos órgãos oficiais e nas marcas de materiais esportivos.

Assim, foi realizada uma observação flutuante das postagens dos perfis de órgãos oficiais, representados por: @fifaworldcup, @olympics, @timebrasil (Comitê Olímpico brasileiro) e @cbf_futebol; assim como de marcas de materiais esportivos: @nike, @ reebok, @reebokbrasil, @adidas, @adidasbrasil, @puma e @pumabrasil. Os perfis escolhidos respeitaram o critério de relevância a partir do número de seguidores, buscando contemplar aqueles de considerável abrangência mundial e também nacional. Todos os perfis foram analisados buscando identificar as características de publicações que eram realizadas, priorizando aquelas que apresentavam algum tipo de representação sensualizada da mulher. O período de análise foi o ano de 2018 , entre os dias $1^{\circ}$ de janeiro e 
31 de dezembro, compondo uma amostra de 1.776 imagens (fotos e vídeos). Conforme já destacado, em 2018 foi realizada a Copa do Mundo de Futebol na Rússia, que, entre outros aspectos, trouxe à tona questões de gênero e exploração de imagens femininas de forma sensualizada.

Após analisar as imagens postadas pelos perfis foi possível tecer algumas observações iniciais. Os órgãos oficiais têm um foco institucional, principalmente com imagens dos atletas (tanto homens quanto mulheres) e das competições; porém, é rara a presença de algum tipo de imagem com um viés sensualizado da figura feminina. Logo, o recorte final se concentrou apenas nos perfis das marcas esportivas. Ao analisar essas marcas esportivas, a Nike foi a única empresa entre as analisadas que não possuía um perfil exclusivo do Brasil, apenas um único global. Todos os perfis apresentaram modos similares de publicações, com as imagens de atletas e figuras famosas patrocinadas, da prática esportiva e de produtos. Observando as postagens, há quatro tipos de categorias relacionadas ao gênero predominante enfocado nas imagens, sendo elas: a) homem; b) mulher; c) homem e mulher; d) produto. Na Imagem 1, destacamos alguns exemplos. 


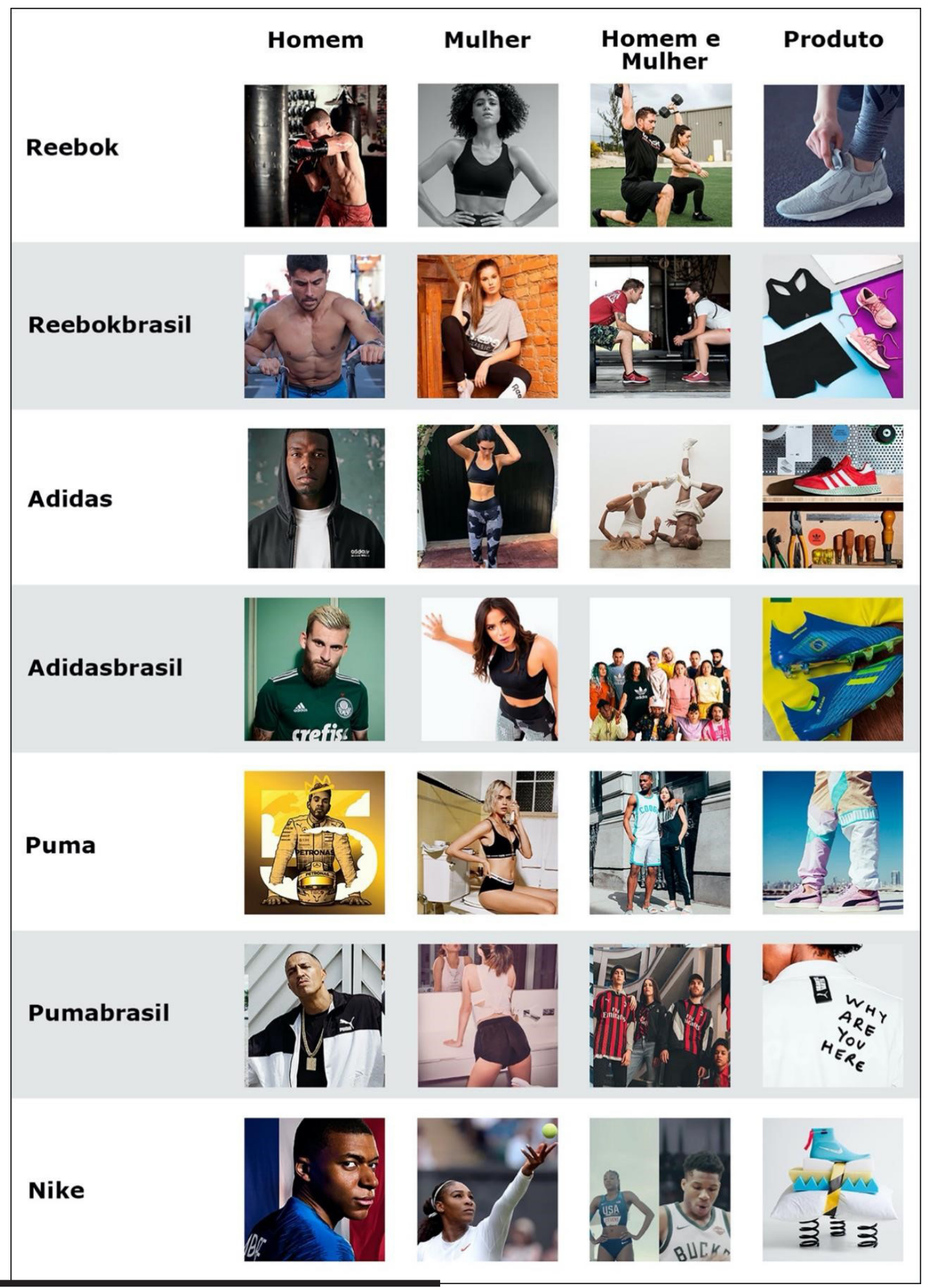

Imagem 1-Categorias de gêneros de postagens encontradas. Fonte: Elaborado pelos autores a partir das coletas nos perfis do Instagram @ Reebok,@Reebokbrasil, @Adidas, @Adidasbrasil, @Puma, @Pumabrasile @Nike. 
A partir dessas categorias, foi verificada sua distribuição de frequência nas publicações, conforme o Quadro 1.

\begin{tabular}{|l|c|c|c|c|c|}
\hline Marca & $\begin{array}{c}\text { Total de imagens } \\
\text { postadas }\end{array}$ & Homem & Mulher & $\begin{array}{c}\text { Homem e } \\
\text { Mulher }\end{array}$ & Produto \\
\hline Reebok & 384 & $27,1 \%$ & $\mathbf{4 5 , 8} \%$ & $4,2 \%$ & $22,9 \%$ \\
\hline Reebokbrasil & 348 & $18,4 \%$ & $\mathbf{6 0 , 3} \%$ & $4,6 \%$ & $16,7 \%$ \\
\hline Adidas & 212 & $\mathbf{3 5 , 8} \%$ & $25,0 \%$ & $9,0 \%$ & $30,2 \%$ \\
\hline Adidasbrasil & 246 & $36,6 \%$ & $12,2 \%$ & $4,5 \%$ & $\mathbf{4 6 , 7 \%}$ \\
\hline Puma & 262 & $21,8 \%$ & $22,5 \%$ & $3,8 \%$ & $\mathbf{5 1 , 9 \%}$ \\
\hline Pumabrasil & 324 & $26,9 \%$ & $26,9 \%$ & $4,0 \%$ & $\mathbf{4 2 , 3} \%$ \\
\hline Nike & 55 & $\mathbf{6 3 , 6} \%$ & $21,8 \%$ & $5,5 \%$ & $9,1 \%$ \\
\hline
\end{tabular}

Quadro 1 - Gêneros dos perfis das marcas esportivas no Instagram. Fonte: Elaborado pelos autores a partir das coletas.

Observou-se uma variação entre os tipos de postagens mais frequentes das marcas. Os perfis da Reebok apresentaram prioritariamente enfoque nas mulheres, sendo que a conta brasileira teve um índice de mais de $60 \%$ de imagens femininas. A Adidas teve um enfoque maior em imagens masculinas e de produtos, tendo no perfil global o foco em homens $(35,5 \%)$ e no brasileiro em produtos $(46,7 \%)$. Já a Puma priorizou imagens de produtos, com uma incidência de 51,9\% no perfil global e 42,3\% no brasileiro. Por sua vez, a Nike enfatizou as imagens de homens em 63,6\%.

Ao realizar um somatório de frequência em todos os perfis, notou-se um equilíbrio entre os tipos de postagens, com o gênero feminino atingindo 35,3\% e o masculino 34\%, seguidos de produtos com 28,9\%, como mostra o Gráfico 1. As postagens com ambos os gêneros em destaque apresentaram apenas $5 \%$ de frequência. 


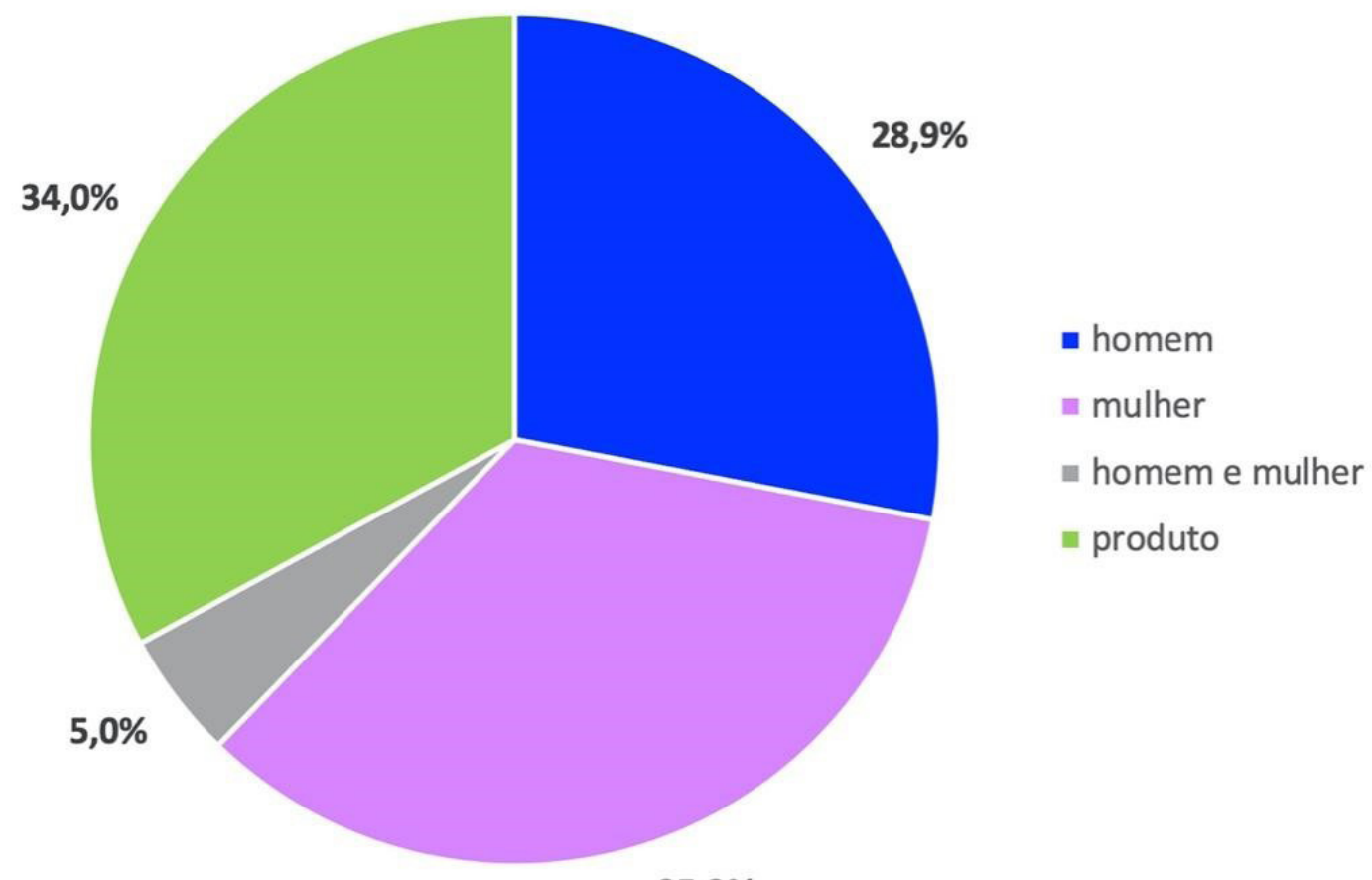

$35,3 \%$

Gráfico 1 - Percentual total de imagens por gênero nos perfis das marcas esportivas.

Fonte: Elaborado pelos autores a partir das coletas nos perfis do Instagram @Reebok, @ Reebokbrasil,@Adidas, @Adidasbrasil, @Puma, @Pumabrasile @Nike.

Analisando os perfis individualmente, considerando exclusivamente o foco na representação dos gêneros, foi possível identificar que a marca Reebok utiliza principalmente imagens femininas, enquanto as marcas Adidas e Nike imagens masculinas, e a Puma apresentou um equilíbrio entre ambos os gêneros, como pode ser observado no Gráfico 2. 


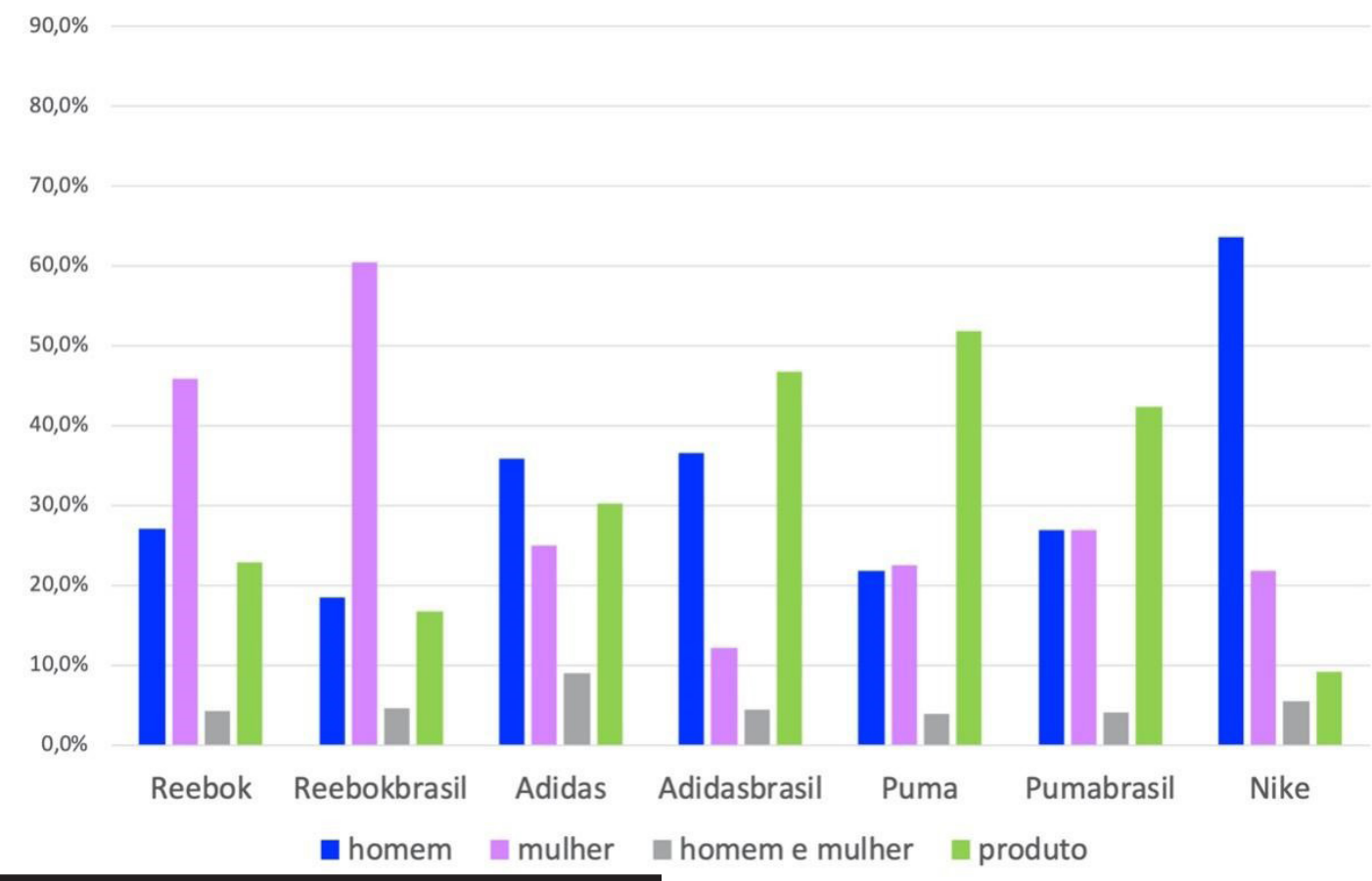

Gráfico 2 - Categoria de imagens por gênero nos perfis das marcas esportivas.

Fonte: Elaborado pelos autores a partir das

coletas nos perfis do Instagram.

Foi possível verificar no volume geral que as marcas esportivas apresentaram equilíbrio de gênero e produtos representados nas publicações. A análise individual dos perfis concluiu que a Reebok utilizou mais mulheres, Adidas e Nike mais homens, enquanto a Puma manteve uma proporcionalidade. Contudo, a partir desses dados iniciais, a análise qualitativa das imagens apresentou um padrão característico, haja vista que algumas postagens específicas do gênero feminino chamaram a atenção no que tange à forma como a imagem das mulheres foi explorada.

\section{CELEBRIDADES SÍMBOLOS SEXUAIS E AS MARCAS ESPORTIVAS}

Todos os perfis analisados, com exceção da Nike, apresentaram imagens com celebridades femininas internacionais (não relacionadas ao âmbito esportivo) patrocinadas, como: as cantoras Dua Lipa (Adidas), Rihanna (Puma), Selena Gomez (Puma) e Ariana Grande (Reebok); as modelos Cara Delevingne (Puma), Gigi Hadid (Reebok) e Adriana Lima (Puma). Além delas, os perfis brasileiros também contaram com celebridades nacionais, como as cantoras Anitta (Adidas Brasil) e Ludmila (Puma Brasil), além das atrizes Paolla de Oliveira (Reebok Brasil), Bruna Marquezine (Puma Brasil) e Camila Queiroz (Reebok Brasil). Como pode ser observado na Imagem 2, grande parte das imagens postadas com essas artistas apresentaram um viés de editorial de moda, com as celebridades posando com produtos das marcas. 


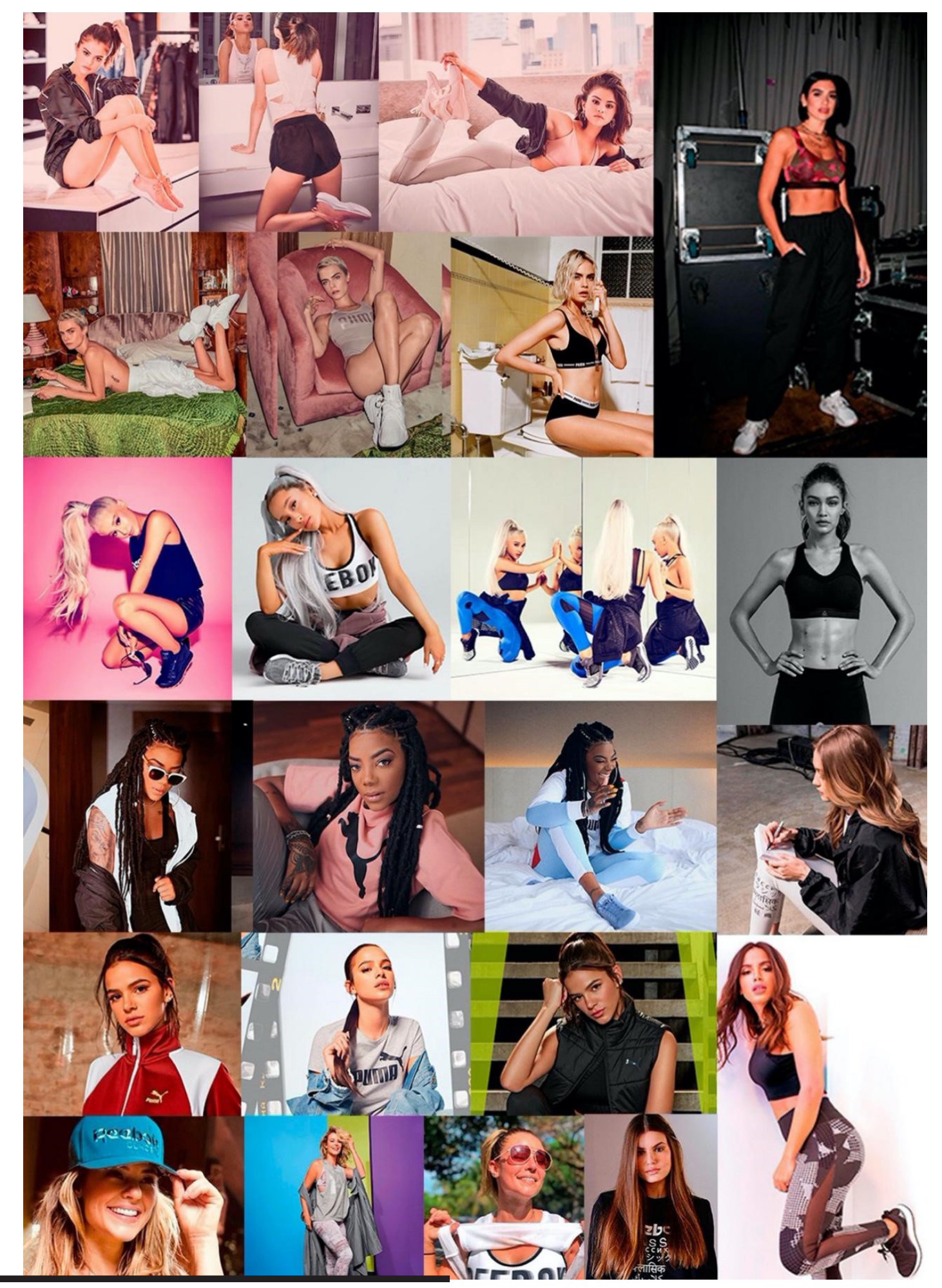

Imagem 2 - Postagens com celebridades

nacionais e internacionais. Fonte: Elaborado

pelos autores a partir das coletas nos perfis do

Instagram.

Apesar do padrão das roupas esportivas femininas valorizar o corpo da mulher, seja pelas vestimentas justas ou pelos tamanhos reduzidos, de um modo geral, não pareceu haver nenhuma forma de apelo sexual ou erótico nas publicações, principalmente em postagens com celebridades internacionais. Contudo, ao analisar a representação 
das celebridades nos perfis brasileiros foi identificado uma tendência em comum: em algum momento, ocorreram tentativas de uma utilização sensualizada das celebridades nacionais patrocinadas pelas marcas, compondo, de algum modo, o imaginário nacional ligado a esse tema e já anteriormente associado a essas figuras públicas.

A Reebok Brasil tem como embaixadora a atriz Paolla de Oliveira, que integra a campanha "Be more human" juntamente com outras celebridades femininas mundiais. O site oficial da marca (REEBOK, 2018) apresenta um texto e um vídeo de estreia da atriz como garota propaganda (dia 18 de julho de 2018). Cabe destacar que o texto do site conta a trajetória artística da Paolla, citando também as duas eleições da atriz como "Mulher mais sexy do mundo" em premiação da Revista Vip, nos anos de 2013 e 2017. No que tange ao tema sensualidade, é possível afirmar que Paolla Oliveira teve relevância considerável nos últimos anos. Em 2015, ao aparecer de costas com uma calcinha fio dental na minissérie "Felizes para sempre" da Globo, a cena ganhou repercussão nacional, sendo amplamente divulgada nas redes sociais, chegando a ocupar os Trending Topics do Twitter (BUMBUM..., 2015). Três anos mais tarde, a atriz foi vítima de um vazamento de suas fotos nuas durante a gravação da série "Assédio" (março de 2018), que também gerou grande reverberação midiática (VIEIRA, 2018).

A Puma Brasil apresenta como garota propaganda a atriz Bruna Marquezine, escolhida embaixadora da marca juntamente com Rihanna e Cara Delevigne, em anúncio realizado no dia 5 de junho de 2018 (MARIANO, 2018).

A atriz também foi eleita a "Mulher mais sexy do mundo" pela Revista Vip em 2014, um ano depois da primeira eleição de Paolla Oliveira (“VIP”..., 2014). A carreira de Bruna começou ainda na infância, participando de diversas telenovelas. Porém, foi em 2012, com então 17 anos, ao interpretar a sensual "Lurdinha" em "Salve Jorge", que a atriz começou a ter destaque na mídia (SANTOS, 2015). Em 2013, participou do programa "Dança dos Famosos", onde seu vídeo dançando funk sensualmente teve grande destaque (BRUNA..., 2016a). Já em 2016, protagonizou a série "Nada será como antes", com diversas cenas de nudez e sexo (MAIA, 2016; BRUNA..., 2016b).

Anitta tem uma proximidade com a marca Adidas desde 2017, quando estampou as roupas da marca no clipe "Sua Cara" (POR QUE..., 2017). Em 2018, a cantora participou diretamente de ações promocionais da empresa e chegou a realizar "treinamentos físicos" com clientes da marca (MENINA..., 2018). Anitta também foi eleita a "Mulher mais sexy do mundo" em 2015, coincidentemente logo após Bruna Marquezine. Com notoriedade no âmbito artístico, ela esbanja sensualidade em seus clipes. Em 2017, o vídeo da música "Vai Malandra" exibiu a artista usando um biquíni minúsculo confeccionado com fita isolante em diversos closes sensuais, o que também gerou muita repercussão (“VAI..., 2017). 
$\mathrm{O}$ uso de celebridades femininas consideradas símbolos sexuais por marcas em campanhas publicitárias é algo recorrente e compreensível. No diálogo com Gill (2007, p.149) entende-se que o uso de celebridades consideradas símbolos sexuais em campanhas publicitárias é atravessado pela vigilância, disciplina e remodelação dos corpos femininos, "a fim de estar em conformidade com as decisões, cada vez mais estreitas, da atratividade feminina".

Todavia, chama a atenção o que parece ser uma "disputa" das marcas esportivas em seus perfis do Instagram para vincularem suas imagens a essas referências femininas sensualizadas do momento. Em meio a todo esse contexto que preza pela não exploração da imagem da mulher como objeto, tanto na propaganda quanto no âmbito esportivo, algumas postagens das marcas no Brasil parecem acentuar, mesmo que ocasionalmente, a erotização dessas mulheres que compõe o “imaginário sensual nacional”. Foi possível encontrar ao menos uma postagem de cada marca, a partir do último trimestre de 2018, que exploravam, de algum modo, a sensualidade, como mostra a Quadro 2.

\begin{tabular}{|l|l|l|l|}
\hline Marca & Celebridade & Data do post & Post \\
\hline $\begin{array}{l}\text { Reebok } \\
\text { Brasil }\end{array}$ & $\begin{array}{l}\text { Paolla de } \\
\text { Oliveira }\end{array}$ & $20 / 09 / 2018$ & https://www.instagram.com/p/Bn9bDPiHVhK/ \\
\hline $\begin{array}{l}\text { Puma } \\
\text { Brasil }\end{array}$ & $\begin{array}{l}\text { Bruna } \\
\text { Marquezine }\end{array}$ & $28 / 09 / 2018$ & $\begin{array}{l}\text { https://www.instagram.com/stories/highlights/17 } \\
962928026089477 /\end{array}$ \\
\hline $\begin{array}{l}\text { Adidas } \\
\text { Brasil }\end{array}$ & Anitta & $20 / 11 / 2018$ & $\begin{array}{l}\text { https://www.instagram.com/stories/highlights/17 } \\
983057222076684 /\end{array}$ \\
\hline
\end{tabular}

Quadro 2 - Postagens analisadas. Fonte: Publi-

cado no perfil @reebokbrasil no Instagram.

Disponivel em: https://vimeo.com/322025303.

Acesso em: 25 set. 2020.

Nas Imagens 3 a 5 são apresentados frames de momentos representativos desse possível viés erótico das postagens, onde as atrizes parecem dançar sensualmente. 


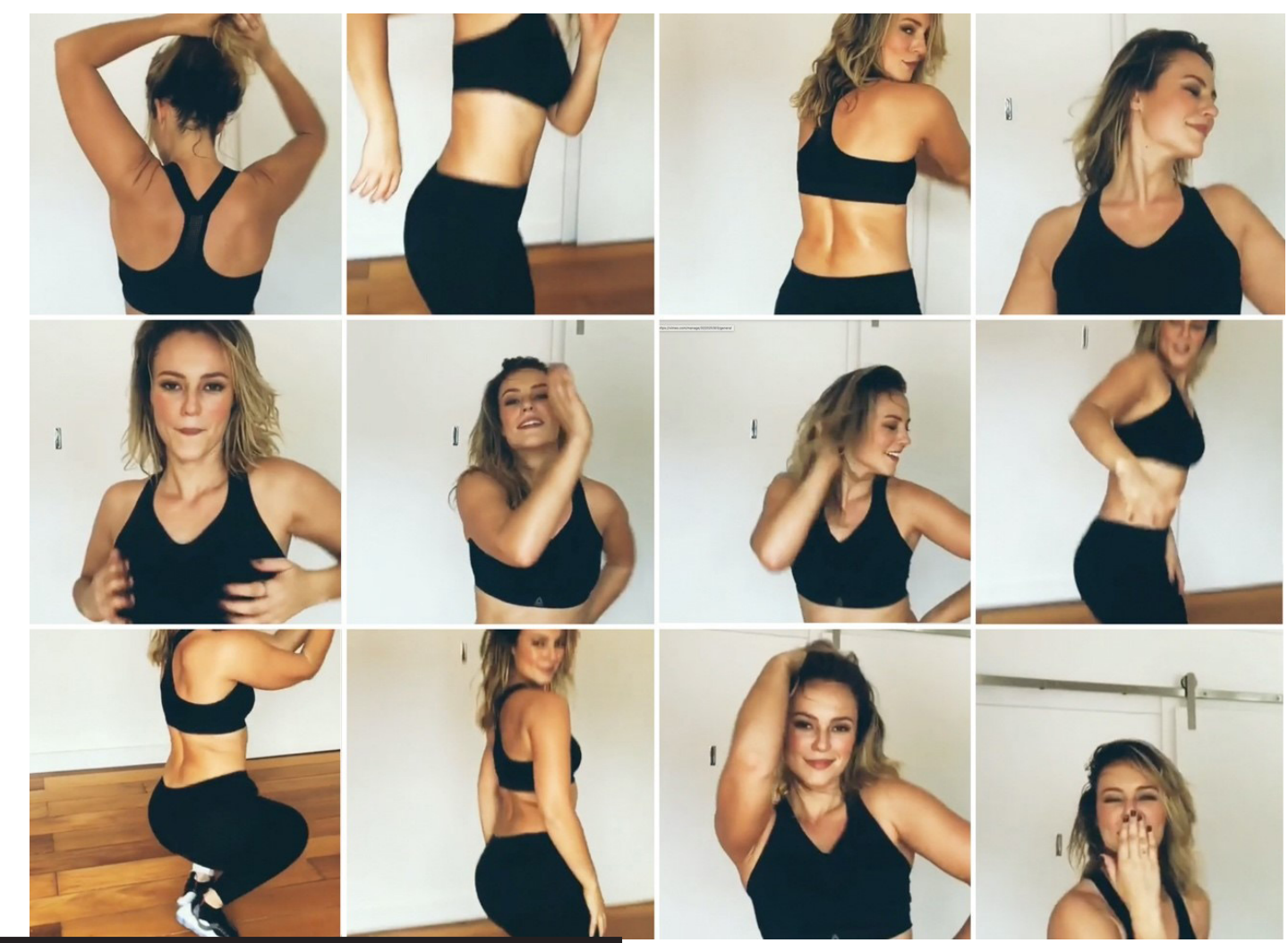

${ }^{6}$ Pure Move Bra é um top esportivo com tecnologia exclusiva desenvolvido pela Reebok. Disponível em: https://www. youtube.com/watch?v=-m0CiT2JG3I. Acesso em: 7 dez. 2018

Imagem 3 - Frames ilustrativos - Paolla Oliveira

- @reebokbrasil. Fonte: Publicado no perfil @reebokbrasil no Instagram. Disponível em:

https://vimeo.com/322025303. Acesso em: 25 set. 2020.

No dia 20 de setembro a Reebok patrocinou e repostou uma publicação de Paolla Oliveira onde ela aparece dançando de forma sensual, contudo o texto da postagem aparentemente busca destacar o produto Pure Move $\mathrm{Bra}^{6}$, top lançado pela marca. No entanto, ao assistir ao vídeo é pouco provável não se inferir a presença da sensualidade nas imagens, que podem acabam por afastar um possível enfoque no produto. Ao verificar a campanha global da marca com as demais embaixadoras internacionais, nota-se uma representação diferente, que ao contrário do perfil Brasil, busca enfatizar a prática e movimentos esportivos . Na postagem a atriz dança de forma sensual, passando a mão pelo corpo e cabelos suados, olhando de forma provocativa para a câmera. Os enquadramentos são sempre fechados, possivelmente para focar nos produtos, mas invariavelmente revelando também as curvas e o corpo da personagem, como costas, seios, barriga, pernas e quadris. 


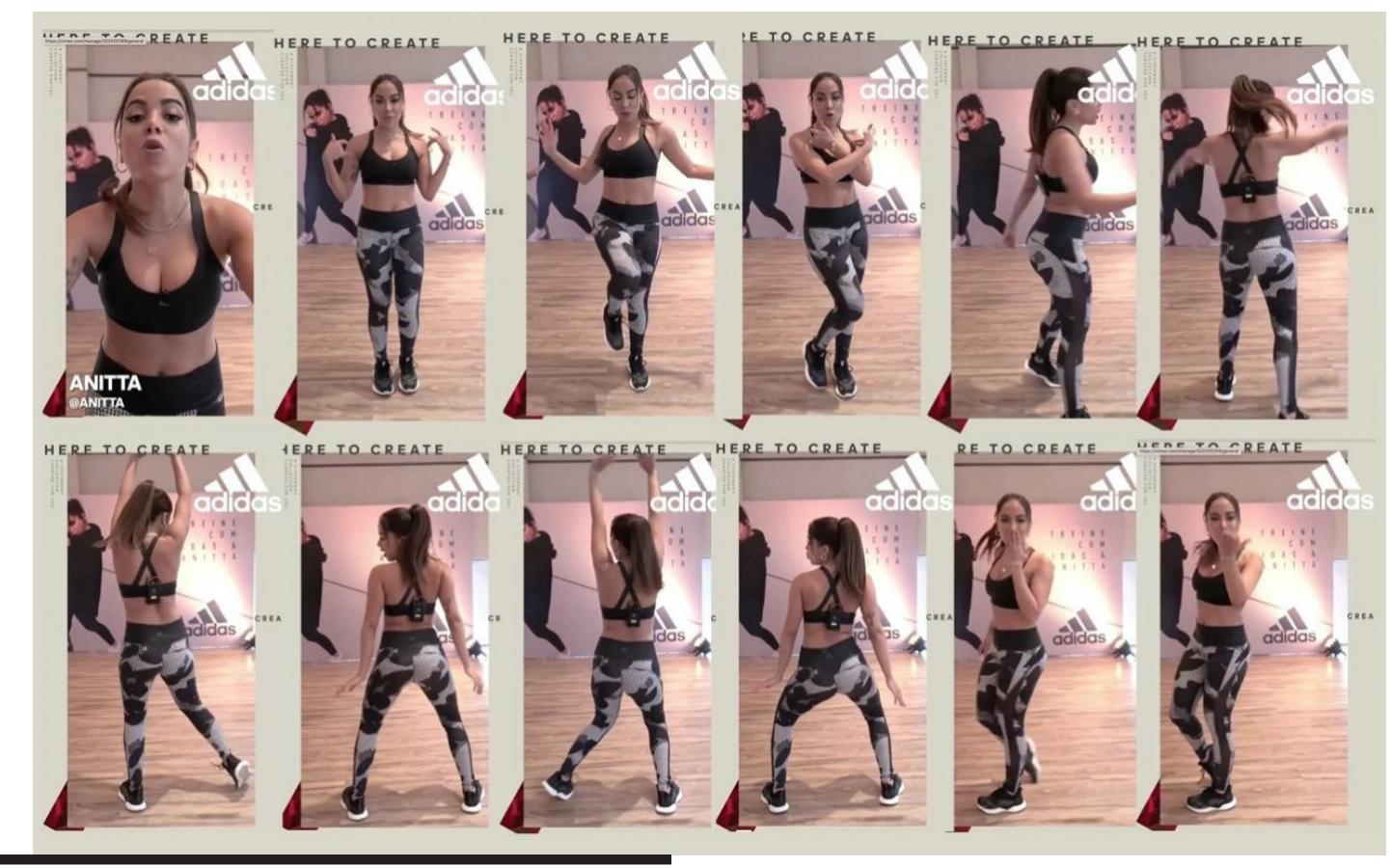

Imagem 4 - Frames ilustrativos - Anitta - @

adidasbrasil. Fonte: Publicados no perfil @

adidasbrasil no Instagram. Disponíveis em:

https://vimeo.com/322025188 e https://vimeo.

com/322025204. Acesso em: 25 set. 2020.

Em novembro de 2018, a Adidas fez uma postagem patrocinada destinada a divulgar uma promoção para concorrer a um treino com a cantora Anitta, em que ela aparece ensinando os passos da coreografia da música "Vai Malandra". Diferente do vídeo da Reebok, nas postagens da Adidas a câmera é fixa com um plano de corpo inteiro, ficando a cargo da própria coreografia apresentar um caráter mais erotizado, na qual predominam os movimentos de quadril com a cantora de costas em diversos momentos. A sensualidade da publicação pode ser explicada pela relação com as coreografias da cantora. Contudo, ainda assim, é possível questionar o quanto essa prática acaba por não priorizar questões femininas relacionadas ao esporte ou aos produtos. Ressalta-se que, apesar de serem marcas distintas, a Reebok foi comprada pela Adidas em 2005 (ADIDAS..., 2005), o que pode apontar uma certa tendência estratégica nas abordagens apresentadas pela empresa mantenedora. 

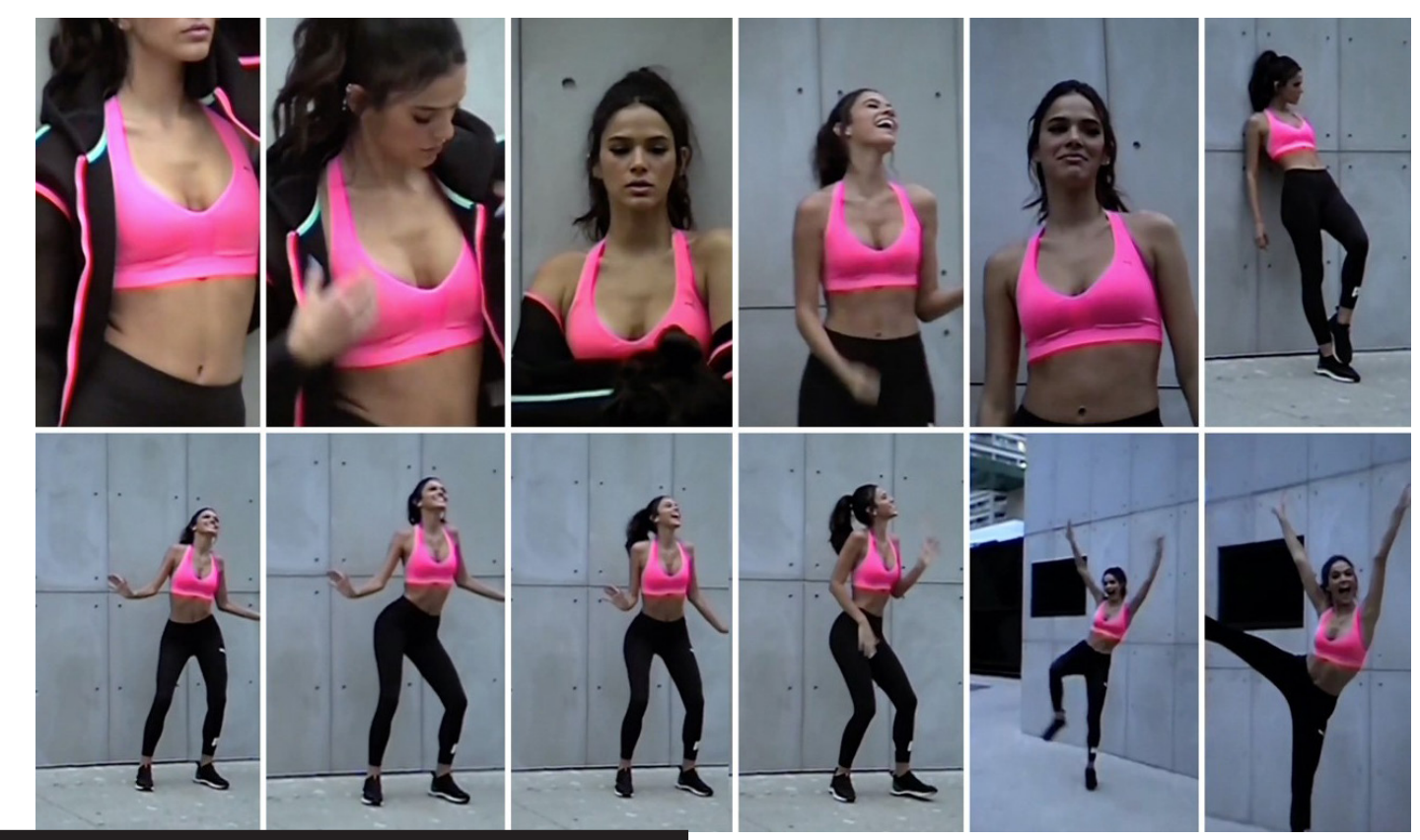

Imagem 5 - Frames ilustrativos - Bruna Marquezine - @pumabrasil. Fonte: Publicadono perfil @pumabrasil no Instagram. Disponíveis em: https://vimeo.com/322025231, https:// vimeo.com/322025255 e https://vimeo. com/322025282. Acesso em: 25 set. 2020.

A Puma Brasil apresentou uma abordagem mais sutil no que tange à questão das representações femininas de modo sensual. Porém, na postagem do dia 28 de setembro, apesar da diferença dos demais vídeos, por ter um enfoque em closes que realçam os produtos, existem alguns momentos em que a sensualidade da atriz Bruna Marquezine também parece ser explorada, por vezes, com planos fechados no corpo da atriz e em outros momentos em planos mais abertos com a atriz movimentando os quadris de forma muito similar à coreografia da Anitta, no vídeo anterior.

Em todos os vídeos, as personagens utilizam produtos das marcas, com tênis, uma calça colada ao corpo e um top esportivo deixando a barriga amostra. Porém, as percepções de sensualidade não residem nas vestimentas, mas sim no comportamento e movimentação das mulheres ao longo das postagens, com as roupas auxiliando na sensualização das cenas, salientando o corpo e as curvas das modelos.

\section{CONSIDERAÇÕES FINAIS}

Ao relacionar questões da objetificação da mulher com o contexto esportivo juntamente com ações comunicacionais das marcas esportivas no Instagram, foram identificadas algumas possíveis inferências que apontam para diferentes movimentos. Enquanto as instituições e órgãos oficiais ligados ao esporte tendem a evitar a banalização de imagens femininas com viés sensual, parece que as marcas, inseridas em um âmbito 
mais comercial e mercadológico, ainda exploram e nutrem esse imaginário presente, principalmente, dentro do mercado brasileiro. Foram identificadas posturas diferentes entre a marca líder de mercado, Nike, em relação às demais, pois, além de não possuir um perfil local, a Nike tem um comportamento muito próximo aos dos órgãos esportivos. Já as marcas concorrentes apresentaram uma conduta diferente no Instagram, tendo em vista que além de possuírem perfis globais e nacionais, também se apropriam de figuras públicas sem ligação direta com o esporte.

Apesar de todas as mulheres analisadas representarem aspectos representativos dessa "nova mulher", destacado por Santaella (2008) e Lipovetsky (2000), ao analisar o contexto brasileiro, parece ainda haver resquícios de uma sociedade patriarcal, como citam Segato (2003), Freyre (2002) e Bocayuva (2001). Tal aspecto fica visível ao observar as marcas que optaram por utilizar figuras femininas nacionais, que além de buscar uma aproximação com o público-alvo brasileiro, apropriaram-se de referências que vinculam e compõem, de alguma forma, o já concebido "imaginário sensual nacional" (LESSA, 2005; BELELI, 2007; GOLDENBERG, 2010; MALHEIROS; PADILLA, 2015).

Apesar dos avanços do que parece ser um movimento contra a banalização da imagem feminina sensualizada, tanto na publicidade quanto nos esportes, ainda existem algumas vertentes, principalmente comerciais, que seguem nutrindo o imaginário da mulher como objeto. A observação do Instagram mostrou que, apesar de órgãos, entidades e marcas internacionais, não usarem algum tipo de simbolismo erótico, os perfis brasileiros das marcas parecem ainda se aproveitar do imaginário nacional do sensual, ainda disseminado pelos meios de comunicação, para buscar a venda de produtos. Coincidência ou não, algumas das principais mulheres brasileiras consideradas símbolos sexuais nacionais estão vinculadas a marcas esportivas nacionais e em algum momento enfatizaram o viés sensual. Isso parece indicar que, apesar dos esforços das demais partes, ainda existe espaço para tal representação.

\section{REFERÊNCIAS BIBLIOGRÁFICAS}

"VAI Malandra": 7 detalhes inusitados do clipe de Anitta. Catraca Livre, [s.l.], 20 dez. 2017. Disponível em: https://catracalivre.com.br/entretenimento/vai-malandra-7-detalhes-inusitados-do-clipe-de-anitta. Acesso em: 7 dez. 2018.

"VIP”: com Marquezine em 1º, veja lista das 100 mais sexy. Terra, São Paulo, 31 out. 2014. Disponível em: https://www.terra.com.br/diversao/gente/vip-com-marquezine-em-1-veja-lista-das-100-mais-sexy,aa5cc990a9769410VgnVCM20000099cceb0aRCRD.html. Acesso em: 7 dez. 2018.

ADIDAS compra Reebok por 3,1 bilhões. Folha de São Paulo, São Paulo, 4 ago. 2005. Disponível em:https://www1.folha.uol.com.br/fsp/dinheiro/fi0408200534. htm. Acesso em: 7 dez. 2018. 
BELELI, I. Corpo e identidade na propaganda. Revista Estudos Feministas, v. 15, n. 1, p. 193-215, 2007.

BOCAYUVA, H. Erotismo à brasileira: o excesso sexual na obra de Gilberto Freyre. Rio de Janeiro: Garamond, 2001.

BOURDIEU, P. A Dominação Masculina. Rio de Janeiro: Bertrand Brasil, 1999.

BRUNA Marquezine e o funk: relembre a apresentação épica da atriz no "Dança dos Famosos 2013”. GSHOW, [s./l], 23 set. 2016a. Disponível em: http://gshow.globo. $\mathrm{com} / \mathrm{tv} /$ noticia/2016/09/bruna-marquezine-e-o-funk-relembre-apresentacao-epica-da-atriz-no-danca-dos-famosos-2013.html. Acesso em: 7 dez. 2018.

BRUNA Marquezine rouba a cena com nudez em "Nada Será Como Antes" e diz: "Papel mais desafiador da minha carreira". Caras, [s.l.], 14 dez. 2016b. Disponível em: https://caras.uol.com.br/tv/bruna-marquezine-rouba-cena-com-nudez-em-nada-sera-como-antes-papel-mais-desafiador-da-carreira.phtml. Acesso em: 7 dez. 2018.

BUMBUM de Paolla Oliveira chega a Trending Topics e viraliza na web. G1, São Paulo, 29 jan. 2015. Disponível em: http://g1.globo.com/tecnologia/noticia/2015/01/ bumbum-de-paolla-oliveira-chega-trending-topics-e-viraliza-na-web.html. Acesso em: 7 dez. 2018.

CAMPBELL, C. Eu compro, logo sei que existo: as bases metafísicas do consumo moderno. In: Cultura, consumo e identidade. Rio de Janeiro: FGV, 2006. p. 47-64.

CHADE, J. Quarenta e cinco casos de assédio sexual foram oficialmente registrados durante a Copa. Estadão, São Paulo, 11 jul. 2018. Disponível em: https://esportes. estadao.com.br/noticias/futebol,quarenta-e-cinco-casos-de-assedio-sexual-foram-oficialmente-registrados-durante-a-copa,70002398347. Acesso em: 7 dez. 2018.

COM 50 milhões de usuários, Brasil é segundo no ranking do Instagram. Folha de São Paulo, São Paulo, 28 out. 2017. Disponível em: https://www1.folha. uol.com.br/mercado/2017/10/1931057-com-50-milhoes-de-usuarios-brasil-e-segundo-no-ranking-do-instagram.shtml. Acesso em: 8 dez. 2018.

COPLE, J. Lei que proíbe propaganda sexista no Rio prevê multa de até R\$ 1,3 milhão. O Globo, Rio de Janeiro, 10 jan. 2018. Disponível em: https://oglobo.globo.com/ sociedade/lei-que-proibe-propaganda-sexista-no-rio-preve-multa-de-ate-13-milhao-22273685. Acesso em: 7 dez. 2018.

DANIELS, E. A.; WARTENA, H. Athlete or Sex Symbol: What Boys Think of Media Representations of Female Athletes. Sex Roles, [s./l], v. 65, n. 7-8, p. 566-579, October 2011.

ECO, U. (org.). História da beleza. Rio de Janeiro: Record, 2004.

FIFA pede a emissoras que evitem filmar "torcedoras atraentes" na Copa. O Globo, Rio de Janeiro, 12 jul. 2018. Disponível em: https://oglobo.globo.com/esportes/fifa- 
-pede-emissoras-que-evitem-filmar-torcedoras-atraentes-na-copa-22878504. Acesso em: 7 dez. 2018.

FOUCAULT, M. Microfísica do poder. São Paulo: Martins Fontes, ed. 15, 2000.

FREDRICKSON, B.; ROBERTS, T. Objectification Theory: Toward Understanding Women's Lived Experiences and Mental Health Risks. Psychology of Women Quarterly, v. 21, n. 2, p. 173-206, June 1997.

FREYRE, G. Casa-grande \& senzala: introdução à história da sociedade patriarcal no Brasil. In: SANTIAGO, S. (Coord.). Intérpretes do Brasil. 2. ed. Rio de Janeiro: Nova Aguilar, 2002. p. 105-645.

GAUNTLETT, D. Media, Gender and Identity. London: Routledge, 2003.

GILL, R. Gender and the media. Cambridge: Polity Press, 2006.

GILL, R. Postfeminist media culture. European Journal of Cultural Studies, v. 10, n. 2, p. 147-166, May 2007.

GOELLNER, S. V. Feminismos, Mulheres E Esportes: Questões Epistemológicas Sobre O Fazer Historiográfico. Movimento (ESEFID/UFRGS), v. 13, n. 2, p. 173-196, 2008 .

GOLDENBERG, M. The body as capital: Understanding Brazilian Culture Mirian. Vibrant, v. 7, n. 1, p. 220-238, 2010.

HOLMES, J. Olimpíada - 1936: glória do Reich de Hitler. Rio de Janeiro: Renes, 1974.

INSTAGRAM superou 1 bilhão de usuários ativos. Exame, [s./l], 20 jun. 2018. Disponível em: https://exame.abril.com.br/tecnologia/instagram-superou-1-bilhao-de-usuarios-ativos. Acesso em: 8 dez. 2018.

IOC. Gender Equality Review Project. Comitê Olímpico Internacional, [s.l.], 2014a. Disponível em: https://www.olympic.org/ /media/Document\%20Library/OlympicOrg/News/2018/03/IOC-Gender-Equality-Review-Project-Recommendations-Overview-March-2018.pdf. Acesso em: 7 dez. 2018.

IOC. Olympic Agenda 2020. Comitê Olímpico Internacional, [s.l.], 2014b. Disponível em: https://stillmed.olympic.org/media/Document\%20Library/OlympicOrg/Documents/Olympic-Agenda-2020/Olympic-Agenda-2020-20-20-Recommendations. pdf\#_ga $=2.97360412 .2036472589 .1543955714-2123450029.1543955714$. Acesso em: 7 dez. 2018.

LARISSA Riquelme: a paraguaia que virou a "Namorada do Mundial". Globo Esporte, Rio de Janeiro, 6 jul. 2010. Disponível em: http://globoesporte.globo.com/futebol/ copa-do-mundo/fotos/2010/07/larissa-riquelme-paraguaia-que-virou-namorada-do-mundial.html. Acesso em: 7 dez. 2018. 
LEHRER, J. Proust foi um neurocientista. Rio de Janeiro: Bestseller, 2010.

LESSA, P. Mulheres à venda. Londrina: Eduel, 2005.

LIPOVETSKY, G. A terceira mulher: permanência e evolução do papel feminino. São Paulo: Companhia das Letras, 2000.

LIPOVETSKY, G. O império do efêmero: A moda e seu destino nas sociedades modernas. São Paulo: Companhia das Letras, 1989.

MAIA, M. C. Bruna Marquezine encara nudez e morte em "Nada Será Como Antes". Veja, [s./l], 14 dez. 2016. Disponível em: https://veja.abril.com.br/entretenimento/ bruna-marquezine-encara-nudez-e-morte-em-nada-sera-como-antes. Acesso em: 7 dez. 2018.

MAIS um: novo vídeo de assédio de brasileiros a estrangeiras é divulgado. UOL, São Paulo, 20 jun. 2018. Disponível em: https://esporte.uol.com.br/futebol/copa-do-mundo/2018/noticias/2018/06/20/mais-um-novo-video-de-assedio-de-brasileiros-a-estrangeiras-e-divulgado.htm. Acesso em: 7 dez. 2018.

MALHEIROS, J.; PADILLA, B. Can stigma become a resource? The mobilisation of aesthetic-corporal capital by female immigrant entrepreneurs from Brazil. Identities, v. 22, n. 6, p. 687-705, 2015.

MANOVICH, L. Instagram and contemporary image. [s.l: s.n.], 2016. Disponível em: http://manovich.net/index.php/projects/instagram-and-contemporary-image. Acesso em: 13 set. 2021.

MARIANO, T. Bruna Marquezine é anunciada como embaixadora da Puma no Brasil. Pure People, [s./l], 5 jun. 2018. Disponível em: http://www.purepeople.com.br/ noticia/bruna-marquezine-sera-garota-propaganda-da-puma-no-brasil_a230774/1. Acesso em: 7 dez. 2018.

MATOS, J. E. Getty publica fotos de "torcedoras mais sexy", é criticada e pede desculpas. UOL, São Paulo, 27 jun. 2018. Disponível em: https://esporte.uol.com.br/ futebol/copa-do-mundo/2018/noticias/2018/06/27/getty-publica-fotos-de-torcedoras-mais-sexy-e-criticada-e-pede-desculpas.htm. Acesso em: 7 dez. 2018.

MENINA de ouro da Adidas, Anitta agora até treina com clientes da marca. UOL Esporte, São Paulo, 1 nov. 2018. Disponível em: https://navitrine.blogosfera.uol.com. br/2018/11/01/menina-de-ouro-da-adidas-anitta-agora-ate-treina-com-clientes-da-marca. Acesso em: 7 dez. 2018.

MILLER, D. Consumo como cultura material. Horizontes Antropológicos, v. 13, n. 28, p. 33-63, 2007.

MORENO, R. A imagem da mulher na mídia. São Paulo: Publisher, 2012. 
POR QUE Anitta virou a menina de ouro da Adidas? UOL Esporte, São Paulo, 27 out. 2017. Disponível em: https://navitrine.blogosfera.uol.com.br/2017/10/27/por-que-anitta-virou-a-menina-de-ouro-da-adidas. Acesso em: 7 dez. 2018.

REEBOK Women - Paolla Oliveira. Reebok Brasil, [s./l], 2018. Disponível em: https://brasil.reebokwomenlatam.com/teamreebok/paolla-oliveira. Acesso em: $7 \mathrm{dez}$. 2018.

SABISTON, C.; WILSON, B. Britney, the Body and the Blurring of Popular Cultures: A Case Study of Music Videos, Gender, a Transcendent Celebrity, and Health Issues. In: FULLER, L. K. (Ed.). Sport, rhetoric, and gender: historical perspectives and media representations. New York: Palgrave Macmillan, 2006. p. 199-210.

SALVINI, L.; SOUZA, J.; MARCHI JUNIOR, W. A violência simbólica e a dominação masculina no campo esportivo: algumas notas e digressões teóricas. Revista Brasileira de Educação Física e Esporte, v. 26, n. 3, p. 401-410, 2012.

SANTAELLA, L. Mulheres em tempos de modernidade líquida. In: Comunicação \& Cultura, n. 6, 2008. p. 105-113.

SANTOS, E. Bruna Marquezine completa 20 anos: relembre vida, personagens e amores. EGO, Rio de Janeiro, 4 ago. 2015. Disponível em: http://ego.globo.com/famosos/ noticia/2015/08/bruna-marquezine-completa-20-anos-relembre-vida-personagens-e-amores.html. Acesso em: 7 dez. 2018.

SEGATO, R. L. Las estructuras elementales de la violencia. Ensayos sobre género entre la antropología, el psicoanálisis y los derechos humanos. Bernal: Universidad Nacional de Quilmes, 2003.

VIEIRA, S. Paolla Oliveira sobre vazamento de fotos: "Sigo minha vida sem ter vergonha de nada". Revista Quem, [s./l], 4 mar. 2018. Disponível em: https://revistaquem. globo.com/QUEM-News/noticia/2018/03/paolla-oliveira-sobre-vazamento-de-fotos-sigo-minha-vida-sem-ter-vergonha-de-nada.html. Acesso em: 7 dez. 2018.

WARD, L. M. et al. Sexuality and entertainment media. In: APA handbook of sexuality and psychology: Contextual approaches. Washington: American Psychological Association, 2013. p. 373-423.

WARD, L. M.; HARRISON, K. The impact of media use on girls' beliefs about gender roles, their bodies, and sexual relationships: A research synthesis. In: COLE, E.; DANIEL, J. H. (ed.). Featuring females: Feminist analyses of media. Washington: American Psychological Association, 2005. p. 2-23. 